\title{
Chronic hypertension and pregnancy outcomes: systematic review and meta-analysis
}

\author{
(c) $(1)(9)$ OPEN ACCESS
}

Kate Bramham clinical research fellow, Bethany Parnell medical student, Catherine Nelson-Piercy
professor of obstetric medicine, Paul T Seed senior lecturer in medical statistics, Lucilla Poston
professor of Women's Health, Lucy C Chappell clinical senior lecturer in maternal and fetal medicine

Division of Women's Health, Women's Health Academic Centre, King's College London and King's Health Partners, St Thomas' Hospital, London SE1 7EH, United Kingdom

\begin{abstract}
Objective To provide an accurate assessment of complications of pregnancy in women with chronic hypertension, including comparison with population pregnancy data (US) to inform pre-pregnancy and antenatal management strategies.

Design Systematic review and meta-analysis.

Data sources Embase, Medline, and Web of Science were searched without language restrictions, from first publication until June 2013; the bibliographies of relevant articles and reviews were hand searched for additional reports.
\end{abstract}

Study selection Studies involving pregnant women with chronic hypertension, including retrospective and prospective cohorts, population studies, and appropriate arms of randomised controlled trials, were included.

Data extraction Pooled incidence for each pregnancy outcome was reported and, for US studies, compared with US general population incidence from the National Vital Statistics Report (2006).

Results 55 eligible studies were identified, encompassing 795221 pregnancies. Women with chronic hypertension had high pooled incidences of superimposed pre-eclampsia (25.9\%, 95\% confidence interval $21.0 \%$ to $31.5 \%$ ), caesarean section ( $41.4 \%$, $35.5 \%$ to $47.7 \%$ ), preterm delivery <37 weeks' gestation ( $28.1 \%$ (22.6 to $34.4 \%)$, birth weight $<2500 \mathrm{~g}(16.9 \%, 13.1 \%$ to $21.5 \%)$, neonatal unit admission (20.5\%, $15.7 \%$ to $26.4 \%$ ), and perinatal death (4.0\%, $2.9 \%$ to $5.4 \%$ ). However, considerable heterogeneity existed in the reported incidence of all outcomes $\left(\tau^{2}=0.286-0.766\right)$, with a substantial range of incidences in individual studies around these averages; additional meta-regression did not identify any influential demographic factors. The incidences (the meta-analysis average from US studies) of adverse outcomes in women with chronic hypertension were compared with women from the US national population dataset and showed higher risks in those with chronic hypertension: relative risks were 7.7 (95\% confidence interval 5.7 to 10.1) for superimposed pre-eclampsia compared with pre-eclampsia, 1.3 (1.1 to 1.5$)$ for caesarean section, 2.7 (1.9 to 3.6 ) for preterm delivery
$<37$ weeks' gestation, 2.7 (1.9 to 3.8) for birth weight <2500 g, 3.2 (2.2 to 4.4 ) for neonatal unit admission, and 4.2 (2.7 to 6.5$)$ for perinatal death.

Conclusions This systematic review, reporting meta-analysed data from studies of pregnant women with chronic hypertension, shows that adverse outcomes of pregnancy are common and emphasises a need for heightened antenatal surveillance. A consistent strategy to study women with chronic hypertension is needed, as previous study designs have been diverse. These findings should inform counselling and contribute to optimisation of maternal health, drug treatment, and pre-pregnancy management in women affected by chronic hypertension.

\section{Introduction}

Chronic hypertension complicates between $1 \%$ and $5 \%$ of pregnancies, ${ }^{1-4}$ but this estimate is drawn from a small number of population based studies, including publications from more than 20 years ago. Recent demographic changes in the antenatal population suggest that chronic hypertension in pregnancy may be an increasing clinical problem. In populations in which maternal age at childbirth is increasing, the association of hypertension with advancing age will inevitably contribute to a greater prevalence of chronic hypertension. ${ }^{5}$ In the United States, for example, chronic hypertension is likely to have paralleled the increase in first deliveries in women aged over 35 years from $1 \%$ to $8 \%$ that occurred between 1970 and $2006 .{ }^{6}$ Maternal age may not be the only factor; a recent population based study in the United States suggests that the prevalence of chronic hypertension in pregnancy increased between 1995-96 and 2007-08, despite adjustment for maternal age. ${ }^{4}$ An increase in other risk factors for chronic hypertension, including obesity and the metabolic syndrome, is likely to contribute. ${ }^{78}$ Globally, therefore, the number of women entering pregnancy with established chronic hypertension is set to rise. 
Chronic hypertension is associated with poor outcomes of pregnancy. ${ }^{10}$ Numerous case-control studies frequently identify chronic hypertension as a risk factor for most known adverse events for mother and fetus. ${ }^{11-13}$ Retrospective and prospective cohort studies, intervention trials, and observational studies for high risk pregnancies similarly document higher rates of complications of pregnancy in women with chronic hypertension. ${ }^{814-16}$ Individually, these reports, usually from single centre studies, provide valuable data for a given population, but they are of limited use for wider extrapolation. Nevertheless, collectively, they may enable accurate assessment of pregnancy outcomes in affected women.

Primary and secondary healthcare professionals involved in the management of women of childbearing age with chronic hypertension include family doctors, clinical pharmacologists, cardiologists, nephrologists, endocrinologists, and general physicians. All may be called on to provide information for women planning a pregnancy. Pregnancy is frequently the first time when chronic hypertension is identified by midwives and obstetricians. ${ }^{17}$ In the absence of a strong evidence base for accurate risk assessment in chronic hypertension, providing useful estimates of adverse pregnancy outcomes presents a challenge. The objective of this study was to conduct a meta-analysis of population based, multicentre, and single centre studies, to provide a reliable assessment of risks of pregnancy in women with chronic hypertension, drawing comparison with outcomes available from US studies and the US general population (2006) of pregnant women.

\section{Methods}

\section{Literature review}

We did a comprehensive literature review using the databases PubMed/Medline (via OVID), Embase (via OVID), and Web of Science. We tailored search strategies to each database. We used MeSH and free text terms in conjunction to increase sensitivity to potentially appropriate studies. Where MeSH terms were not used (Web of Science), we identified search terms and all possible synonyms and spellings obtained and used them in the search strategy. In Web of Science, we selected the "lemmatisation" option. We searched pregnancy complications and outcomes terms and chronic hypertension terms separately, and then combined them in each database. The study protocol is provided in supplementary information 1 . We applied no limits other than the search strategy to databases. We searched databases from the time of first publication (Medline 1946, Embase 1947, Web of Science 1899) until June 2013.

\section{Study selection criteria}

We included prospective and retrospective cohort studies. We reviewed randomised controlled trials, excluding the treatment arm if a difference existed in outcomes and including both arms if no benefit of the intervention was seen. We excluded case-control studies, case reports, reviews, letters to editors, and animal/in vitro studies.

To minimise selection bias, we did not include studies that excluded women with superimposed pre-eclampsia or categorised women with chronic hypertension and superimposed pre-eclampsia together with low risk women with pre-eclampsia, as this was one of the outcomes of interest. We considered studies with fewer than 20 women with chronic hypertension to be non-representative, and we excluded studies that did not report relevant outcome data.

\section{Data extraction}

$\mathrm{KB}$ and BP independently reviewed abstracts and full texts, and LC reviewed any discrepancies. The same authors independently extracted and tabulated data from selected full texts. When two studies included the same cohort, we included only the report with the largest number of women or most relevant outcomes.

We followed PRISMA guidelines for all procedures and reporting. ${ }^{18}$ We used the Newcastle-Ottawa scale to grade cohort studies. We considered multi-fetal gestations as one pregnancy for maternal outcomes and two pregnancies for fetal outcomes. We recorded details of other potential confounders and adjustments, including age, secondary hypertension, body mass index, weight, parity, smoking, and ethnicity. Manuscripts not published in English were translated by native speaking physicians. We included abstracts if a definition of chronic hypertension and relevant outcomes were described.

We examined and reported definitions of chronic hypertension and superimposed pre-eclampsia (when available) for each included study. For purposes of analysis, we used the following definitions: preterm delivery-delivery before 37 weeks' gestation (up to $36^{+6}$ ); low birth weight—-below 2500 g; perinatal death - fetal death after 20 weeks' gestation including stillbirth and neonatal death up to 1 month; neonatal unit

admission-admission to neonatal intensive care or special care baby unit.

\section{Statistical analysis}

We used mixed effects logistic regression for meta-analysis, using the Stata command "xtmelogit." We used extracted data to calculate estimated pooled incidences, $95 \%$ confidence intervals, and predicted $95 \%$ incidence ranges (prediction intervals) of adverse outcomes. Prediction intervals have been proposed as being akin to a reference range for that parameter across the population, allowing more appropriate interpretation and extrapolation into clinical practice. ${ }^{19}$ Ninety five per cent prediction intervals show the uncertainty of the range of possible percentage incidences for a new study population, whereas $95 \%$ confidence intervals show the uncertainty about the estimate of the average percentage incidence across study populations.

We used mixed effects logistic regression, which allows for random variation at more than one level, on the assumption that significant heterogeneity would exist both between individuals and between studies and that each study would be likely to include covariates that could influence outcomes. We used the $\tau^{2}$ statistic to describe heterogeneity and did subgroup analyses according to seven groupings selected before analysis: country's economic wealth according to World Bank classification (gross national income per capita), ${ }^{20}$ study period, inclusion or exclusion of multiple pregnancies, inclusion or exclusion of congenital abnormalities, inclusion or exclusion of women with secondary hypertension, study design, and study definition of chronic hypertension. We also stratified studies reporting incidences of superimposed pre-eclampsia according to the study definition of superimposed pre-eclampsia. We used forest plots to assess overall effect. We calculated risk ratios for US studies relative to separate comparator data obtained from the Centers for Disease Control and Prevention's vital statistics 2006 (US national statistics) for pooled incidences and for individual study outcomes. ${ }^{21}$

We also did meta-regression using "xtmelogit" regression to identify the influence of potential modifiers of outcome including parity, maternal age, and ethnicity on the relation between chronic hypertension and subsequent outcome. As individual level data were unavailable, we used aggregate data 
for each study (mean and standard deviation for age, and proportions of nulliparous/multiparous and white/non-white women). We made estimates of mean age if categories of ranges were presented. We used Stata version 11 for all statistical analyses, and all tests and confidence intervals were two sided with a significance level of 0.05 .

\section{Results}

Figure $1 \Downarrow$ shows the study selection process. Following title/abstract screening, 208 papers remained for full text review. Four abstracts were unavailable for analysis despite repeated attempts to contact the authors. Fifty five studies, comprising 795221 pregnancies and 812772 infants, met inclusion criteria and are reported in tables $1 \Downarrow, 2 \Downarrow, 3 \Downarrow$, and $4 \Downarrow . .^{15}{ }^{1622-74}$ All studies achieved a total Newcastle-Ottawa grading score of 5 to 7 , and no studies were excluded following grading. Newcastle-Ottawa gradings are shown in supplementary information 2 .

Five studies were randomised controlled trials, including a primary analysis, ${ }^{16}$ three secondary analyses of studies that did not have differences between treatment and placebo arms, ${ }^{1522} 24$ and one study that reported a difference in outcomes between the treatment (L-arginine supplementation) and placebo arm, ${ }^{23}$ so only the placebo arm was included. One study included both prospective and retrospective data and was categorised as retrospective as this was the larger group. ${ }^{32}$

Maternal demographics of women with chronic hypertension, if reported, are shown in online supplementary information 2 . Individual study definitions of chronic hypertension and categories according to definition are shown in tables $1 \Downarrow, 2 \Downarrow$, $3 \Downarrow$, and $4 \Downarrow$ and in more detail in online supplementary information 3. Study definitions for superimposed pre-eclampsia are shown in online supplementary information 4 . Table $5 \Downarrow$ shows pooled incidences and prediction intervals of adverse pregnancy outcomes. Table $6 \Downarrow$ shows risk ratios of adverse pregnancy outcomes from US studies compared with US population data.

The relative risk of superimposed pre-eclampsia in women with chronic hypertension was on average across study populations nearly eightfold higher than was pre-eclampsia in the general pregnancy population, and all adverse neonatal outcomes were at least twice as likely to occur compared with the general population.

The meta-analysis summary results and $95 \%$ confidence intervals relate to the average percentage incidence across studies. However, heterogeneity existed in most analyses, as seen by $\tau^{2}$ values above zero. Thus genuine variation in incidences exists across study populations; in other words, in some populations the true incidence is well above the average, and in others it is well below the average. This is shown by wide $95 \%$ prediction intervals for the potential percentage incidence in a new study population. Only the limits of the prediction interval for superimposed pre-eclampsia excluded the US national data incidence of pre-eclampsia, which shows that the increased rate was evident across the different settings of the studies.

Figures $2 \Downarrow, 3 \Downarrow, 4 \Downarrow, 5 \Downarrow, 6 \Downarrow$, and $7 \Downarrow$ show forest plots for the pooled incidence of superimposed pre-eclampsia, caesarean section, preterm delivery before 37 weeks' gestation, birth weight $<2500 \mathrm{~g}$, perinatal death, and neonatal unit admission. Heterogeneity of incidence of superimposed pre-eclampsia seemed to be lower in randomised controlled trials $\left(\tau^{2}=0.026\right)$ than in population studies $\left(\tau^{2}=0.438\right)$ and was greater in prospective cohort $\left(\tau^{2}=0.83\right)$ and retrospective cohort studies $\left(\tau^{2}=1.080\right)$. Stratification of studies according to study definitions of superimposed pre-eclampsia did not further reduce heterogeneity measured by $\tau^{2}$. The incidence of neonatal unit admission was lower in one population study $(7.1 \%, 95 \%$ confidence interval $6.0 \%$ to $9.2 \%$ ) compared with randomised controlled trials $(20.1 \%, 19.5 \%$ to $24.3 \%)$, but only one population study was included in this subgroup analysis. Further comparison of $\tau^{2}$ did not identify any significant influence of multiple pregnancies, congenital abnormalities, period of delivery, country's economic wealth, inclusion of secondary hypertension, maternal age, parity, ethnicity, or study definition of chronic hypertension on the degree of heterogeneity ( $\tau^{2}>0.2$ for all subgroups) or proportion of women with adverse events.

\section{Discussion}

This meta-analysis of 55 studies from 25 countries, including 795221 pregnancies and spanning four decades, confirms that chronic hypertension is associated with adverse pregnancy outcomes. The pooled average incidence, across study populations, of superimposed pre-eclampsia, caesarean section, preterm delivery before 37 weeks' gestation, birth weight $<2500$ $\mathrm{g}$, perinatal death, and neonatal unit admission were all significantly higher in US studies than the general US pregnancy population. Moreover, for superimposed pre-eclampsia, the limits of the $95 \%$ prediction intervals (reference range) for the US based studies were higher than the rate of pre-eclampsia reported in the US population. Heterogeneity between studies existed, and $95 \%$ prediction intervals were broad. Incidences of superimposed pre-eclampsia reported by randomised controlled trials were less heterogeneous than for other study designs but similar to the overall pooled incidence of superimposed pre-eclampsia in women with chronic hypertension. However, meta-regression did not identify any other underlying causes of heterogeneity, suggesting that either populations with chronic hypertension are varied or determination of chronic hypertension and outcomes may not be consistent.

\section{Strengths and weaknesses of study}

Studies were carefully selected according to a rigorous search strategy to enable unbiased inclusion of retrospectively or prospectively studied cohorts, population studies, or randomised controlled trials. For example, superimposed pre-eclampsia has been shown to be associated with worse pregnancy outcomes, ${ }^{15}{ }^{75-79}$ but some reports, initially assessed for the purpose of this study, excluded women with chronic hypertension and superimposed pre-eclampsia. This would lead to an underestimation of other adverse events, so we did not include these publications in the analysis. In other studies, women with superimposed pre-eclampsia were frequently grouped with other women with pre-eclampsia alone, precluding useful risk assessment for women with chronic hypertension. These studies were also excluded from meta-analysis.

Despite the selection of relevant and appropriately performed studies, we observed substantial diversity of reported incidences of adverse outcome. This is likely to reflect variations in the selection of women studied and difficulties of measurement but also true differences within the population of women with chronic hypertension. We conducted exploration to identify important confounders, including maternal age, ethnicity, economic wealth of country, decade of deliveries reported, parity, inclusion of secondary hypertension, multiple pregnancies and congenital birth defects, study design, and study definition of chronic hypertension. Although randomised controlled trials 
were more consistent than other study designs, we found no systematic differences in mean event rates to explain the disparity in outcomes. Most papers did not report relevant baseline demographics defining the population studied, which limited the assessment of confounders. Coexisting factors including maternal age and ethnicity, recognised to be associated with both chronic hypertension and adverse pregnancy outcome, may contribute to confounding, but their relative effects are unknown.

Few studies in the meta-analysis reported control data, so a direct comparison of outcomes between women with chronic hypertension and normotensive women was not possible. To provide clinical context and relevance, we selected US population data $(2006)^{21}$ as a separate population for comparison against the US chronic hypertension studies, because these data provide the most comprehensive national annual statistics.

Although US population data also report outcomes in high risk women, including those with chronic hypertension, the proportion of women with chronic hypertension in this dataset is small and therefore unlikely to influence the overall incidence of adverse outcomes. We chose the dataset from 2006 as being sufficiently recent to be clinically relevant but not too chronologically distant from the years in which most of the studies were conducted.

We could not elucidate the effect of differing antihypertensive treatments on the maternal and perinatal outcomes, as insufficient information was provided to allow subanalysis by drug group. This problem is made more complex by scenarios that include changing treatment over the gestation-for example, when a pregnant woman starts pregnancy while taking one drug, stops all treatment during the mid-trimester blood pressure nadir, and then restarts with a different drug when her blood pressure exceeds a certain threshold. In addition, many population based registry studies may record prescriptions from a database, rather than provide data that confirm that treatment has been taken. Thus assigning an individual woman to any drug treatment is difficult even within trimesters.

\section{Strengths and weaknesses in relation to other studies}

To our knowledge, few other detailed meta-analyses of outcomes of pregnancy in women with chronic hypertension have been reported. Population studies have reported data from large numbers of women with chronic hypertension and can be a useful guide to risks of pregnancy, but their generalisability is unclear. Population studies are limited by inaccuracies of coding collected for billing purposes and are susceptible to under-recognition of hypertension in pregnancy and misclassification. For example, Roberts and colleagues compared hospital discharge and birth databases with medical records and identified significant under-reporting of chronic hypertension. ${ }^{3}$ Inadequacies of coding are also particularly relevant to accurate diagnosis of pre-eclampsia. ${ }^{80}$ Women are more likely to be reported to have chronic hypertension if it had been recorded in an admission before pregnancy, ${ }^{3}$ suggesting that women with more severe or longstanding chronic hypertension may be more likely to be included in population studies.

No threshold of blood pressure that predicts poor pregnancy outcomes has been identified, and an association between both systolic and diastolic blood pressure and adverse events has been reported. ${ }^{81}$ Similarly, the length of time between diagnosis of hypertension and pregnancy is associated with more adverse events. ${ }^{24}$ Chronic hypertension may be undetectable in early pregnancy owing to systemic vasodilatation and reduced vascular resistance, ${ }^{82}$ resulting in a fall in blood pressure, so women with a blood pressure below 140/90 mm Hg before 20 weeks' gestation would be excluded from many of the studies assessed, unless they were already taking antihypertensive drugs during or before pregnancy. The identification of women with chronic hypertension is therefore challenging, and the fact that multiple different definitions of chronic hypertension were given is unsurprising. This may explain some diversity in incidence of adverse events between studies; however, categorisation of studies according to definition of chronic hypertension did not reduce heterogeneity between outcomes.

In keeping with the challenges of diagnosing chronic hypertension, identification of superimposed pre-eclampsia remains difficult, and uncertainties exist. Research definitions have gone some way towards standardising diagnoses ${ }^{83}$ In this meta-analysis, 16 (30\%) studies did not report diagnostic criteria, and the remainder used 18 varying, though valid, definitions of superimposed pre-eclampsia. Lack of consistency is likely to affect the heterogeneity of outcomes across studies.

Although women with more severe chronic hypertension, managed in specialist clinics, may be over-represented in some cohort studies, pregnancy outcomes did not differ by definition of inclusion criteria. Lack of blood pressures at first antenatal visit or use of antihypertensive drugs in early pregnancy precluded assessment of outcomes by severity of hypertension, although degree of hypertension clearly affects the decision for treatment and outcomes may therefore be influenced by severity. The findings of this study remain applicable to the women with chronic hypertension most frequently encountered and most in need of specialist advice.

\section{Meanings of study and implications for physicians and health providers}

The most recent UK Confidential Enquiry into Maternal and Child Health identified chronic disease as an underlying factor in preventable maternal deaths. ${ }^{84}$ Consequently, the first recommendation stated that "Pre-pregnancy counselling services, ... for women with pre-existing medical illnesses . . . are a key part of maternity services," supported by the National Institute for Health and Care Excellence's guidelines for the management of hypertension in pregnancy. ${ }^{85}$ Furthermore, the American Congress of Obstetricians and Gynecologists' recent practice bulletin recommends that women with chronic hypertension "should be evaluated before conception to ascertain possible end-organ involvement." ${ }^{186}$ Systematic reviews and meta-analyses can provide data more readily inferable to the individual, but no large aggregate analysis of pregnancy outcome in women with chronic hypertension has previously been reported. This meta-analysis of outcomes can be used before pregnancy and antenatally by healthcare professionals (including those not providing direct maternity care) advising women with chronic hypertension regarding possible adverse pregnancy events.

Accessibility to healthcare professionals and facilitation of early referral will allow drug treatment to be optimised on an individual basis (for example, starting aspirin and planning a change from cardio-renoprotective angiotensin converting enzyme inhibitors and angiotensin-II receptor blockers to alternative non-teratogenic antihypertensive drugs at the first positive pregnancy test or pre-pregnancy) or enable reassurance regarding continuation of drugs that are safe in pregnancy, to reduce the risk of complications including cerebrovascular events. 
Debate is ongoing as to how antihypertensive treatment influences outcomes. Although reasonable evidence from a Cochrane systematic review shows that use of antihypertensive drugs halves the incidence of severe hypertension, it has not been shown to affect any other outcomes, including risk of pre-eclampsia, perinatal death, preterm birth, or small for gestational age babies. ${ }^{87}$ Recent work has found that the risk of certain malformations such as congenital heart disease is similar in women taking angiotensin converting enzyme inhibitors and those with underlying hypertension taking no treatment, both having increased risk compared with normotensive controls, suggesting that the hypertension itself may contribute to congenital malformations. ${ }^{88}$ Systematic reviews have also identified that a greater mean difference in mean arterial pressure with antihypertensive treatment is associated with the birth of a higher proportion of small for gestational age infants, ${ }^{89}$ providing the basis for the Chronic Hypertension In Pregnancy Study (CHIPS). This study, which has recently completed recruitment of more than 1000 women with hypertension in pregnancy, but is yet to report, was designed to determine whether tight or less tight blood pressure control influences the likelihood of pregnancy loss or neonatal intensive care unit admission. ${ }^{90}$ A recent study showing that women with chronic hypertension taking antihypertensive drugs have worse perinatal outcomes than do those not on treatment was unable to adjust for severity of underlying hypertension and indicates the need for future prospective studies to explore the influence of pre-existing disease severity. ${ }^{91}$

While the debate on the use and type of antihypertensive drugs continues, other beneficial management strategies needing implementation before or in early pregnancy include lifestyle adjustments (such as weight loss).$^{92}$ Our group has previously shown that women with chronic hypertension who continue to smoke in pregnancy are at greater risk of superimposed pre-eclampsia (compared with non-smokers), so smoking cessation is also an essential component of counselling.

\section{Future research}

Increasing numbers of pregnancies will be complicated by chronic hypertension as the trend continues for women to delay conception, together with the global epidemic of obesity. The consequences of complicated pregnancy outcome are not only costly in the short term, but the long term health consequence for the offspring of women with chronic hypertension and the subsequent financial burden should be acknowledged. ${ }^{93}$ The findings of this meta-analysis support the need for improved understanding of the pathophysiology of chronic hypertension, to inform the development of predictive and diagnostic tools and enhance therapeutic interventions to reduce adverse pregnancy outcomes. The continuing uncertainty about maternal and perinatal effects of antihypertensive treatment shows the need for large observational studies (for example, through population registers) and randomised controlled trials of drug treatment in women with chronic hypertension, to determine optimal management for mother and fetus. As severity of hypertension will always confound need for treatment and perinatal outcomes, this must be considered for appropriate conclusions to be drawn.

\section{Conclusions}

Chronic hypertension is associated with a high incidence of adverse pregnancy outcomes compared with a general population, as exemplified in this report by US data. This finding should be interpreted within the limitations of the study. Our results support the importance of increased antenatal surveillance for women with chronic hypertension to enable early identification of evolving complications. Women should receive pre-pregnancy counselling to optimise their health before pregnancy and to inform them of the increased maternal and fetal risks associated with their hypertension. Strategies to predict those at greatest risk, determine optimal drug treatments, and reduce adverse pregnancy outcomes are needed.

Contributors: KB, BP, and LCC contributed to study conception and design, analysis and interpretation of the data, and drafting and revising of the article and were involved in the final approval of the version to be published. PTS contributed to the analysis and interpretation of the data and revision of the article. CN-P and LP contributed to the interpretation of the data, drafting and revising of the article, and approval of the final paper. LCC is the guarantor.

Funding: This work is produced by KB under the terms of a doctoral research training fellowship issued by the National Institute for Health Research. The views expressed in this publication are those of the author and not necessarily those of the NHS, the National Institute for Health Research, or the Department of Health. PTS's salary is funded by Tommy's Charity.

Competing interests: All authors have completed the ICMJE uniform disclosure form at www.icmje.org/coi_disclosure.pdf (available on request from the corresponding author) and declare: no support from any organisation for the submitted work; no financial relationships with any organisations that might have an interest in the submitted work in the previous three years; no other relationships or activities that could have influenced the submitted work.

\section{Ethical approval: Not needed}

Transparency declaration: LCC affirms that the manuscript is an honest, accurate, and transparent account of the study being reported; that no important aspects of the study have been omitted; and that any discrepancies from the study as planned (and, if relevant, registered) have been explained.

Data sharing: The dataset is available to interested academic parties from the corresponding author.

1 Haddad B, Sibai BM. Chronic hypertension in pregnancy. Ann Med 1999;31:246-52. 2 Livingston JC, Sibai BM. Chronic hypertension in pregnancy. Obstet Gynecol Clin North Am 2001;28:447-63.

3 Roberts CL, Bell JC, Ford JB, Hadfield RM, Algert CS, Morris JM. The accuracy of reporting of the hypertensive disorders of pregnancy in population health data. Hypertens Pregnancy 2008;27:285-97.

4 Bateman BT, Bansil P, Hernandez-Diaz S, Mhyre JM, Callaghan WM, Kuklina EV. Prevalence, trends, and outcomes of chronic hypertension: a nationwide sample of delivery admissions. Am J Obstet Gynecol 2012;206:134.e1-8.

5 Yoder SR, Thornburg LL, Bisognano JD. Hypertension in pregnancy and women of childbearing age. Am J Med 2009;122:890-5.

6 Mathews TJ, Hamilton BE. Delayed childbearing: more women are having their first child later in life. National Center for Health Statistics Data Brief 2009;21.

7 Bayliss H, Churchill D, Beevers M, Beevers DG. Anti-hypertensive drugs in pregnancy and fetal growth: evidence for "pharmacological programming" in the first trimester? Hypertens Pregnancy 2002;21:161-74.

8 Ananth CV, Peedicayil A, Savitz DA. Effect of hypertensive diseases in pregnancy on birthweight, gestational duration, and small-for-gestational-age births. Epidemiology 1995;6:391-5.

9 Seely EW, Ecker J. Chronic hypertension in pregnancy. N Engl J Med 2011;365:439-46.

10 Chesley LC. Toxemia of pregnancy in relation to chronic hypertension. West J Surg Obstet Gynecol 1956;64:284-6.

11 Aagaard-Tillery KM, Holmgren C, Lacoursiere DY, Houssain S, Bloebaum L, Satterfield $\mathrm{R}$, et al. Factors associated with nonanomalous stillbirths: the Utah Stillbirth Database 1992-2002. Am J Obstet Gynecol 2006;194:849-54

12 Ananth C, Peltier M, Smulian J, Vintzileos A. Chronic hypertension and risk of placental abruption: is the association mediated through fetal growth? Am J Obstet Gynecol 2007; 197:273.e1-7.

13 Berg CJ, MacKay AR, Qin C, Callaghan WM. Overview of maternal morbidity during hospitalization for labor and delivery in the United States 1993-1997 and 2001-2005. Obstet Gynecol 2009;113:1075-81.

14 Sibai B, Lecarpentier E, Kayem G, Haddad B, Tsatsaris V, Goffinet F. Adverse maternal and perinatal outcomes in women with chronic hypertension: a retrospective study of 362 patients. Am J Obstet Gynecol 2011;204:S294.

15 Chappell LC, Enye S, Seed P, Briley AL, Poston L, Shennan AH. Adverse perinatal outcomes and risk factors for preeclampsia in women with chronic hypertension: a prospective study. Hypertension 2008;51:1002-9.

16 Weitz C, Khouzami V, Maxwell K, Johnson JW. Treatment of hypertension in pregnancy with methyldopa: a randomized double blind study. Int J Gynaecol Obstet 1987;25:35-40. 


\section{What is already known on this topic}

Women with chronic hypertension have worse outcomes of pregnancy

The magnitude of pregnancy risk for women with chronic hypertension is uncertain from pre-existing data

\section{What this study adds}

This systematic review and meta-analysis shows that women with chronic hypertension have a high pooled incidence of superimposed pre-eclampsia and all other pregnancy complications

Compared with the US general pregnancy population, the incidence of superimposed pre-eclampsia on average across study populations was nearly eightfold higher compared with pre-eclampsia

Women with chronic hypertension in US studies have an approximately threefold increased risk of delivery before 37 weeks' gestation, birth weight $<2500 \mathrm{~g}$, and neonatal intensive care admission and fourfold increased risk of perinatal death compared with the US general pregnancy population

17 Vallejo Vaz AJ, Guisado ML, Garcia-Junco PS, Andreu EP, Morillo SG, Ortiz JV. Differences in the prevalence of metabolic syndrome and levels of C-reactive protein after puerperium in women with hypertensive disorders during pregnancy. Hypertens Res 2010;33:1012-7.

18 Stroup DF, Berlin JA, Morton SC, Olkin I, Williamson GD, Rennie D, et al. Meta-analysis of observational studies in epidemiology: a proposal for reporting. JAMA 2000;283:2008-12

19 Riley RD, Higgins JP, Deeks JJ. Interpretation of random effects meta-analyses. BMJ 2011;342:d549.

20 World Health Organization. Countries and economies. 2013. http://data.worldbank.org/ country.

21 Center for Disease Control and Prevention. Births and natality. 2006. www.cdc.gov/nchs/ fastats/births.htm.

22 August $P$, Helseth $G$, Cook EF, Sison C. A prediction model for superimposed preeclampsia in women with chronic hypertension during pregnancy. Am J Obstet Gynecol 2004;191:1666-72.

23 Neri I, Monari F, Sgarbi L, Berardi A, Masellis G, Facchinetti F. L-arginine supplementation in women with chronic hypertension: impact on blood pressure and maternal and neonatal complications. J Matern Fetal Neonatal Med 2010;23:1456-60

24 Sibai BM, Lindheimer M, Hauth J, Caritis S, VanDorsten P, Klebanoff M, et al. Risk factors for preeclampsia, abruptio placentae, and adverse neonatal outcomes among women with chronic hypertension. N Engl J Med 1998;339:667-71.

25 Allen VM, Joseph KS, Murphy KE, Magee LA, Ohlsson A. The effect of hypertensive disorders in pregnancy on small for gestational age and stillbirth: a population based study. BMC Pregnancy Childbirth 2004;4:17.

26 Bateman BT, Bansil P, Hernandez-Diaz S, Mhyre JM, Callaghan WM, Kuklina EV. Prevalence, trends, and outcomes of chronic hypertension: a nationwide sample of delivery admissions. Am J Obstet Gynecol 2012;206:134.e1-34.e8.

27 Broekhuijsen K, Langenveld J, Van Den Berg P, Ravelli A, Willem Mol B, Franssen M. Maternal and neonatal outcomes of pregnancy in women with chronic hypertension. $A m$ J Obstet Gynecol 2012;1:S344-5.

28 Rasmussen S, Irgens LM. The effects of smoking and hypertensive disorders on fetal growth. BMC Pregnancy Childbirth 2006;6:16.

29 Roberts CL, Algert CS, Morris JM, Ford JB, Henderson-Smart DJ. Hypertensive disorders in pregnancy: a population-based study. Med J Aust 2005;182:332-5.

30 Su CY, Lin HC, Cheng HC, Yen AMF, Chen YH, Kao S. Pregnancy outcomes of anti-hypertensives for women with chronic hypertension: a population-based study. Plos One 2013;8:e53844

31 Zetterstrom K, Lindeberg SN, Haglund B, Hanson U. The association of maternal chronic hypertension with perinatal death in male and female offspring: a record linkage study of 866,188 women. BJOG 2008;115:1436-42.

32 Attolou VNR. Les differents types d'hypertension arterielle chez les femmes enceintes beninoises admises au CNHU de Cotonou [Types of arterial hypertension in pregnant women admitted to the National University Hospital (CNHU), Cotonou, Benin] [French]. Cahiers Sante 1998;8:353-6.

33 Curet LB, Olson RW. Evaluation of a program of bed rest in the treatment of chronic hypertension in pregnancy. Obstet Gynecol 1979;53:336-40.

34 Fleischer A, Schulman H, Farmakides G. Uterine artery Doppler velocimetry in pregnant women with hypertension. Am J Obstet Gynecol 1986;154:806-13.

35 Gant NF, Jimenez JM, Whalley PJ, Chand S, MacDonald PC. A prospective study of angiotensin II pressor responsiveness in pregnancies complicated by chronic essential hypertension. Am J Obstet Gynecol 1977;127:369-75.

36 Hartikainen AL, Aliharmi RH, Rantakallio PT. A cohort study of epidemiological associations and outcomes of pregnancies with hypertensive disorders. Hypertens Pregnancy 1998:17:31-41.

37 Inigo Riesgo CA, Torres Gomez LG, Vargas Gonzalez A, Angulo Vazquez J, Espinoza Ortegon MA. [Chronic high blood pressure in 110 pregnant women] [Spanish]. Ginecol Obstet Mex 2008;76:202-10.

38 Jacquemyn $\mathrm{Y}$, Osmanovic $\mathrm{F}$, Martens $\mathrm{G}$. Preeclampsia and birthweight by gestational age in singleton pregnancies in Flanders, Belgium: a prospective study. Clin Exp Obstet Gynecol 2006;33:96-8.

39 Mabie WC, Pernoll ML, Biswas MK. Chronic hypertension in pregnancy. Obstet Gynecol 1986;67:197-205.

40 Onyiriuka AN, Okolo AA. Small-for-gestational age, ponderal index and neonatal polycythaemia: a study of their association with maternal hypertension among Nigerian women. Ann Afr Med 2005;4:154-59.

41 Ray JG, Burrows RF, Burrows EA, Vermeulen MJ. MOS HIP: McMaster outcome study of hypertension in pregnancy. Early Hum Dev 2001;64:129-43.

42 Rey E, Couturier A. The prognosis of pregnancy in women with chronic hypertension. Am J Obstet Gynecol 1994;171:410-6.

43 Rey E. Preeclampsia and neonatal outcomes in chronic hypertension: comparison between white and black women. Ethn Dis 1997;7:5-11.

44 Roncaglia N, Crippa I, Locatelli A, Cameroni I, Orsenigo F, Vergani P, et al. Prediction of superimposed preeclampsia using uterine artery Doppler velocimetry in women with chronic hypertension. Prenat Diagn 2008;28:710-4.
45 Ruiz Anguas J, Castelazo Morales E, Suarez del Puerto H, Martinez Moreno F, Alvarez Valenzuela J, Bolanos Ancona RA. [Perinatal results in patients with chronic hypertension at the National Institute of Perinatology] [Spanish]. Ginecol Obstet Mex 2001;69:143-50.

46 Segel S, Ananthakrishnan B, Merrill J, Parry S, Macones G, Marder S. Mild chronic hypertension does not confer an increased risk for small for gestational age neonates. Am J Obstet Gynecol 2001;185:S181.

47 Sibai BM, Abdella TN, Anderson GD. Pregnancy outcome in 211 patients with mild chronic hypertension. Obstet Gynecol 1983;61:571-6.

48 Sibai BM, Anderson GD. Pregnancy outcome of intensive therapy in severe hypertension in first trimester. Obstet Gynecol 1986;67:517-22.

49 Sun Y, Yang YL, Yang HX. [Maternal and perinatal prognosis of pregnancy with chronic hypertension and analysis of associated factors] [Chinese]. Zhonghua fu chan ke za zhi 2007;42:434-7.

50 Valsecchi L, Cairone R, Castiglioni MT, Almirante GM, Ferrari A. Serum levels of alpha-tocopherol in hypertensive pregnancies. Hypertens Pregnancy 1999;18:189-95.

51 Zeeman GG, Alexander JM, McIntire DD, Leveno KJ. The significance of antiphospholipid antibodies in pregnant women with chronic hypertension. Am J Perinatol 2004:21:275-9.

52 Ales KL, Charlson ME. The prediction of adverse outcomes in antepartum hypertension. Clin Exp Hypertens B 1989;8:95-112.

53 Bagga R, Aggarwal N, Chopra V, Saha SC, Prasad GRV, Dhaliwal LK. Pregnancy complicated by severe chronic hypertension: a 10-year analysis from a developing country. Hypertens Pregnancy 2007;26:139-49.

54 Banhidy F, Acs N, Puho EH, Czeizel AE. The efficacy of antihypertensive treatment in pregnant women with chronic and gestational hypertension: a population-based study. Hypertens Res 2010;33:460-6.

55 Comino-Delgado R. 'Hypertensive states of pregnancy' in Spain. Clin Exp Hypertens B 1986;5:217-30.

56 Delmis J, Drazancic A, Ivanisevic M, Pfeifer D, Ljubojevic N. [Fetal growth in pregnant women with chronic hypertension] [Croatian]. Lijec Vjesn 1993;115:329-35.

57 Ferrazzani S, Luciano R, Garofalo S, D'Andrea V, De Carolis S, De Carolis MP, et al. Neonatal outcome in hypertensive disorders of pregnancy. Early Hum Dev 2011;87:445-9.

58 Fields SJ, Vainder M, Livshits G, Merlob P, Sirotta L. Obesity and the risk of toxaemia of pregnancy. Ann Hum Biol 1996;23:353-62.

59 Frusca T, Soregaroli M, Zanelli S, Danti L, Guandalini F, Valcamonico A. Role of uterine artery Doppler investigation in pregnant women with chronic hypertension. Eur J Obstet Gynecol Reprod Biol 1998;79:47-50.

60 Gilbert WM, Young AL, Danielsen B. Pregnancy outcomes in women with chronic hypertension: a population-based study. J Reprod Med 2007;52:1046-51.

61 Jain $L$. Effect of pregnancy-induced and chronic hypertension on pregnancy outcome. $J$ Perinatol 1997; 17:425-7.

62 Lecarpentier E, Tsatsaris V, Goffinet F, Cabrol D, Sibai B, Haddad B. Risk factors of superimposed preeclampsia in women with essential chronic hypertension treated before pregnancy. Plos One 2013;8:e62140.

63 Lydakis C, Beevers DG, Beevers M, Lip GY. Obstetric and neonatal outcome following chronic hypertension in pregnancy among different ethnic groups. QJM 1998;91:837-44.

64 Machado MH, Clode N, Graca LM, Cardoso CG. Hypertension associated with pregnancy. Hipertensao associada a gravidez. Estudo epidemiologico de 311 casos consecutivos [Epidemiologic study of 311 consecutive cases] [Portuguese]. Acta Medica Portuguesa 1996;9:7-14.

65 Ono Y, Takagi K, Seki H, Takai Y, Samejima K, Matsunaga S, et al. Neonatal outcome in infants of chronically hypertensive mothers. J Obstet Gynaecol Res 2013;39:1142-6.

66 Parry S, Macones GA, Roth NW, Desperito TJ, Marzullo A, Morgan MA. Antiphospholipid antibodies in chronic hypertension: the value of screening during pregnancy. Am J Perinatol 1998;15:527-31.

67 Pietrantoni M, O'Brien WF. The current impact of the hypertensive disorders of pregnancy. Clin Exp Hypertens 1994;16:479-92.

68 Sass N, Moron AF, el-Kadre D, Camano L, de Almeida PA. Contribuicao ao estudo da gestacao em portadoras de hipertensao arterial cronica [Study of pregnancy with chronic hypertension] [Portuguese]. Revista Paulista de Medicina 1990;108:261-6.

69 Tuuli MG, Rampersad R, Stamilio D, Macones G, Odibo AO. Perinatal outcomes in women with preeclampsia and superimposed preeclampsia: do they differ? Am J Obstet Gynecol 2011;204:508.e1-7.

70 Vanek M, Sheiner E, Levy A, Mazor M. Chronic hypertension and the risk for adverse pregnancy outcome after superimposed pre-eclampsia. Int J Gynaecol Obstet 2004;86:7-11.

71 Velentgas $\mathrm{P}$, Benga-De E, Williams MA. Chronic hypertension, pregnancy-induced hypertension, and low birthweight. Epidemiology 1994:5:345-8.

72 Vigil-De Gracia P, Lasso M, Montufar-Rueda C. Perinatal outcome in women with severe chronic hypertension during the second half of pregnancy. Int $J$ Gynaecol Obstet 2004;85:139-44.

73 Wilson K, Roberts S, McIntire D, Alexander JM. Indication for delivery in pregnant women with chronic hypertension. Am J Obstet Gynecol 2012;1:S343.

74 Zeeman G, Alexander J, McIntire D, Leveno K. Pregnancy outcomes in chronic hypertension compared with the general obstetric population. Am J Obstet Gynecol 2003;189:S89 
75 Sibai BM, Koch MA, Freire S, Pinto e Silva JL, Rudge MVC, Martins-Costa S, et al. The impact of prior preeclampsia on the risk of superimposed preeclampsia and other adverse pregnancy outcomes in patients with chronic hypertension. Am J Obstet Gynecol 2011;204:345.e1-6.

76 Giannubilo SR, Dell'Uomo B, Tranquilli AL. Perinatal outcomes, blood pressure patterns and risk assessment of superimposed preeclampsia in mild chronic hypertensive pregnancy. Eur J Obstet Gynecol Reprod Biol 2006;126:63-7.

77 McCowan LM, Buist RG, North RA, Gamble G. Perinatal morbidity in chronic hypertension. Br J Obstet Gynaecol 1996;103:123-9.

78 Ananth CV, Peltier MR, Kinzler WL, Smulian JC, Vintzileos AM. Chronic hypertension and risk of placental abruption: is the association modified by ischemic placental disease? Am J Obstet Gynecol 2007;197:273.e1-7.

79 Sibai B, Koch M, Freire S, Pinto ES, Rudge MV, Martins-Costa S, et al. Are adverse perinatal outcomes (APOs) in chronic hypertension (CHTN) mostly related to superimposed preeclampsia (PE)? Am J Obstet Gynecol 2012;206:S57.

80 Chappell L, Poulton L, Halligan A, Shennan AH. Lack of consistency in research papers over the definition of pre-eclampsia. Br J Obstet Gynaecol 1999;106:983-5

81 Cnossen JS, Vollebregt KC, de Vrieze N, ter Riet G, Mol BW, Franx A, et al. Accuracy of mean arterial pressure and blood pressure measurements in predicting pre-eclampsia: systematic review and meta-analysis. BMJ 2008:336:1117-20.

82 Duvekot JJ, Cheriex EC, Pieters FA, Menheere PP, Peeters LH. Early pregnancy changes in hemodynamics and volume homeostasis are consecutive adjustments triggered by a primary fall in systemic vascular tone. Am J Obstet Gynecol 1993;169:1382-92.

83 Brown MA, Lindheimer MD, de Swiet M, Van Assche A, Moutquin JM. The classification and diagnosis of the hypertensive disorders of pregnancy: statement from the International Society for the Study of Hypertension in Pregnancy (ISSHP). Hypertens Pregnancy 2001;20:IX-XIV.

84 Centre for Maternal and Child Enquiries (CMACE). Saving mothers' lives: reviewing maternal deaths to make motherhood safer: 2006-08. The eighth report on Confidential Enquiries into Maternal Deaths in the United Kingdom. BJOG 2011;118(suppl 1):1-203.

85 National Institute for Health and Clinical Excellence. Hypertension in pregnancy: the management of hypertensive disorders during pregnancy. NICE, 2010 (available at http: //publications.nice.org.uk/hypertension-in-pregnancy-cg107). (Clinical Guideline 107.)
86 American College of Obstetricians and Gynecologists. ACOG Practice Bulletin No. 125: Chronic hypertension in pregnancy. Obstet Gynecol 2012;119:396-407.

87 Abalos E, Duley L, Steyn DW, Henderson-Smart DJ. Antihypertensive drug therapy for mild to moderate hypertension during pregnancy. Cochrane Database Syst Rev 2007;(1):CD002252.

88 Li DK, Yang C, Andrade S, Tavares V, Ferber JR. Maternal exposure to angiotensin converting enzyme inhibitors in the first trimester and risk of malformations in offspring: a retrospective cohort study. BMJ 2011;343:d5931.

89 Von Dadelszen P, Ornstein MP, Bull SB, Logan AG, Koren G, Magee LA. Fall in mean arterial pressure and fetal growth restriction in pregnancy hypertension: a meta-analysis. Lancet 2000;355:87-92.

90 The CHIPS trial: Control of Hypertension In Pregnancy Study. International Standard Randomised Controlled Trial Register . www.controlled-trials.com/ISRCTN71416914/.

91 Su CY, Lin HC, Cheng HC, Yen AM, Chen YH, Kao S. Pregnancy outcomes of anti-hypertensives for women with chronic hypertension: a population-based study. PloS One 2013;8:e53844.

92 Thangaratinam S, Rogozinska E, Jolly K, Glinkowski S, Roseboom T, Tomlinson JW, et al. Effects of interventions in pregnancy on maternal weight and obstetric outcomes: meta-analysis of randomised evidence. BMJ 2012;344:e2088.

93 Palmsten K, Buka SL, Michels KB. Maternal pregnancy-related hypertension and risk for hypertension in offspring later in life. Obstet Gynecol 2010;116:858-64.

\section{Accepted: 12 March 2014}

\section{Cite this as: BMJ 2014;348:g2301}

This is an Open Access article distributed in accordance with the Creative Commons Attribution Non Commercial (CC BY-NC 3.0) license, which permits others to distribute, remix, adapt, build upon this work non-commercially, and license their derivative works on different terms, provided the original work is properly cited and the use is non-commercial. See: http://creativecommons.org/licenses/by-nc/3.0/. 


\section{Tables}

Table 1| Overview of randomised controlled trials of pregnancy outcomes in women with chronic hypertension included in meta-analysis

\begin{tabular}{|c|c|c|c|c|c|c|c|c|c|}
\hline $\begin{array}{l}\text { Author, year } \\
\text { published }\end{array}$ & Study years & Country & $\begin{array}{c}\text { No of } \\
\text { women }\end{array}$ & $\begin{array}{l}\text { No of } \\
\text { births }\end{array}$ & $\begin{array}{l}\text { Multiple } \\
\text { gestations } \\
\text { included }\end{array}$ & $\begin{array}{c}\text { Secondary causes of } \\
\text { chronic hypertension } \\
\text { excluded }\end{array}$ & $\begin{array}{l}\text { Congenital } \\
\text { abnormalities } \\
\text { excluded }\end{array}$ & $\begin{array}{c}\text { Definition of } \\
\text { chronic } \\
\text { hypertension* }\end{array}$ & $\begin{array}{c}\text { Newcastle-Ottowa } \\
\text { grade }\end{array}$ \\
\hline $\begin{array}{l}\text { August et al, } \\
2004^{22}\end{array}$ & 2003 & USA & 110 & 110 & No & $\begin{array}{c}\text { Creatinine }>1.2 \mathrm{mg} / \mathrm{dL} \\
\text { excluded }\end{array}$ & No & 3 & 7 \\
\hline $\begin{array}{l}\text { Chappell et al, } \\
2008^{15}\end{array}$ & 2003-05 & $\begin{array}{c}\text { UK and } \\
\text { Netherlands }\end{array}$ & 822 & 822 & No & No & No & 2 & 7 \\
\hline Neri et al, $2010^{23}$ & $2006-08$ & Italy & 40 & 40 & No & $\begin{array}{l}\text { Known cardiac or renal } \\
\text { disease excluded }\end{array}$ & Yes & 1 & 6 \\
\hline $\begin{array}{l}\text { Sibai et al, } \\
1998^{24}\end{array}$ & $?-1998$ & USA & 763 & 763 & No & $\begin{array}{l}\text { Type } 1 \text { diabetes } \\
\text { excluded }\end{array}$ & No & 4 & 7 \\
\hline $\begin{array}{l}\text { Weitz et al, } \\
1987^{16}\end{array}$ & $?-1986$ & USA & 25 & 25 & No & $\begin{array}{c}\text { No evidence of } \\
\text { proteinuria (24 hour } \\
\text { urine protein }<100 \mathrm{mg} \text { ) }\end{array}$ & No & 2 & 6 \\
\hline
\end{tabular}

${ }^{*} 1=$ systolic blood pressure $>140$ or diastolic blood pressure $>90 \mathrm{~mm} \mathrm{Hg}$ and/or history of hypertension; $2=$ diastolic blood pressure $>90 \mathrm{~mm} \mathrm{Hg}$ and/or history of hypertension; $3=$ history of hypertension before pregnancy or presence of hypertension before 20 weeks with no blood pressure definition; $4=$ blood pressure $>140 / 90 \mathrm{~mm} \mathrm{Hg}$; $5=$ history of hypertension only; $6=$ antihypertensive drug treatment before 20 weeks; $7=0$ other. 


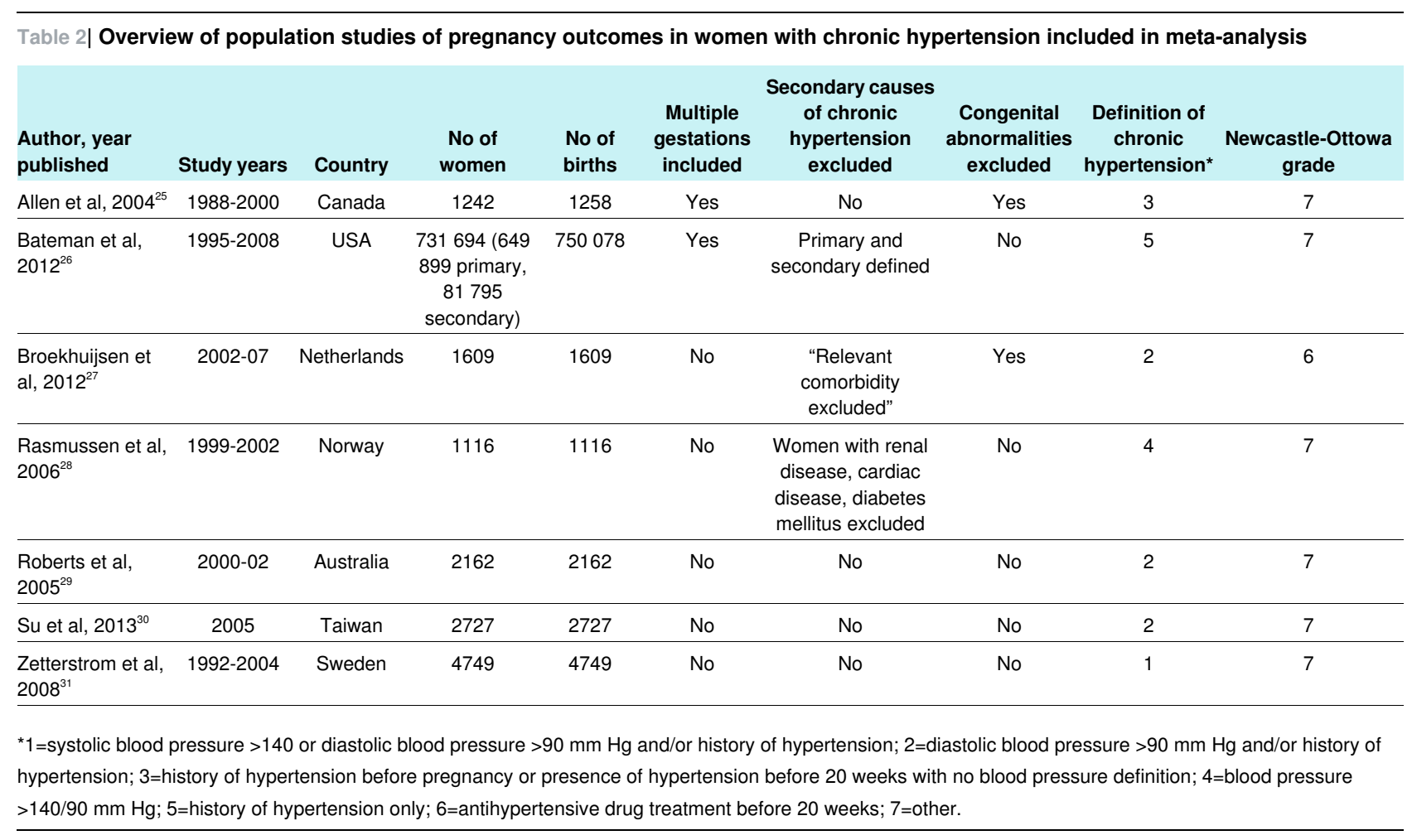




\begin{tabular}{|c|c|c|c|c|c|c|c|c|c|}
\hline $\begin{array}{l}\text { Author, year } \\
\text { published }\end{array}$ & Study years & Country & $\begin{array}{c}\text { No of } \\
\text { women }\end{array}$ & $\begin{array}{l}\text { No of } \\
\text { births }\end{array}$ & $\begin{array}{l}\text { Multiple } \\
\text { gestations } \\
\text { included }\end{array}$ & $\begin{array}{l}\text { Secondary causes } \\
\text { of chronic } \\
\text { hypertension } \\
\text { excluded }\end{array}$ & $\begin{array}{l}\text { Congenital } \\
\text { abnormalities } \\
\text { excluded }\end{array}$ & $\begin{array}{c}\text { Definition of } \\
\text { chronic } \\
\text { hypertension* }\end{array}$ & $\begin{array}{c}\text { Newcastle-Ottowa } \\
\text { grade }\end{array}$ \\
\hline Attolou et al, $1998^{32}$ & $1995-96$ & Benin & 64 & 64 & No & $\begin{array}{l}\text { Cardiac or renal } \\
\text { disease excluded }\end{array}$ & No & 2 & 7 \\
\hline Curet et al, $1979^{33}$ & $1973-79$ & USA & 66 & 72 & Yes & $\begin{array}{l}\text { "No diabetes, cardiac } \\
\text { or renal disease" }\end{array}$ & No & 1 & 6 \\
\hline $\begin{array}{l}\text { Fleischer et al, } \\
1986^{34}\end{array}$ & $1982-84$ & USA & 55 & 55 & No & No & No & 1 & 6 \\
\hline Gant et al, $1977^{35}$ & $?-1977$ & USA & 63 & 63 & No & $\begin{array}{l}\text { "Essential } \\
\text { hypertension only" }\end{array}$ & No & 3 & 6 \\
\hline $\begin{array}{l}\text { Hartikainen et al, } \\
1998^{36}\end{array}$ & $1985-86$ & Finland & 396 & 396 & No & No & No & 1 & 7 \\
\hline $\begin{array}{l}\text { Inigo Riesgo et al, } \\
2008^{37}\end{array}$ & 2001-07 & Mexico & 110 & 110 & No & $\begin{array}{l}\text { "Mild chronic } \\
\text { hypertension without } \\
\text { other disease" }\end{array}$ & No & 1 & 6 \\
\hline $\begin{array}{l}\text { Jacquemyn et al, } \\
2006^{38}\end{array}$ & 2001-02 & Belgium & 2393 & 2393 & No & No & No & 1 & 7 \\
\hline Mabie et al, $1986^{39}$ & $1980-84$ & USA & 156 & 169 & Yes & No & No & 2 & 6 \\
\hline $\begin{array}{l}\text { Onyiriuka and Okolo, } \\
2005^{40}\end{array}$ & $1992-94$ & Nigeria & 20 & 20 & No & $\begin{array}{c}\text { "Free of major } \\
\text { diseases such as } \\
\text { diabetes mellitus, } \\
\text { sickle cell anaemia, } \\
\text { renal failure and heart } \\
\text { disease" }\end{array}$ & No & 2 & 6 \\
\hline Ray, $2001^{41}$ & $1986-95$ & Canada & 459 & 459 & No & No & No & 1 & 7 \\
\hline $\begin{array}{l}\text { Rey and Couturier, } \\
1994^{42}\end{array}$ & $1987-91$ & Canada & 298 & Unknown & Unknown & No & No & 1 & 7 \\
\hline Rey, $1997^{43}$ & $1987-91$ & USA & 208 & 208 & Yes & $\begin{array}{l}\text { Renal disease and } \\
\text { pre-pregnancy } \\
\text { diabetes excluded }\end{array}$ & No & 1 & 7 \\
\hline $\begin{array}{l}\text { Roncaglia et al, } \\
2008^{44}\end{array}$ & 2000-06 & Italy & 182 & 182 & No & $\begin{array}{l}\text { Excluded proteinuria } \\
\text { at first visit }\end{array}$ & Yes & 1 & 7 \\
\hline Ruiz et al, $2001^{45}$ & $1996-97$ & Mexico & 66 & 66 & No & No & No & 5 & 7 \\
\hline Segel et al, $2001^{46}$ & 1995-2001 & USA & 131 & 131 & No & No & No & 1 & 6 \\
\hline Sibai et al, $1983^{47}$ & $1980-82$ & USA & 211 & 215 & No & No & No & 6 & 6 \\
\hline Sibai et al, $1986^{48}$ & 1978-84 & USA & 44 & 44 & No & No & No & 6 & 6 \\
\hline Sun et al, $2007^{49}$ & 2001-05 & China & 121 & 121 & No & No & No & 2 & 7 \\
\hline $\begin{array}{l}\text { Valsecchi et al, } \\
1999^{50}\end{array}$ & 1993-96 & Italy & 26 & 26 & No & No & No & 3 & 6 \\
\hline Zeeman et al, $2004^{51}$ & 1999-2002 & USA & 87 & 87 & No & No & No & 2 & 6 \\
\hline
\end{tabular}

${ }^{*} 1=$ systolic blood pressure $>140$ or diastolic blood pressure $>90 \mathrm{~mm} \mathrm{Hg}$ and/or history of hypertension; 2=diastolic blood pressure $>90 \mathrm{~mm} \mathrm{Hg}$ and/or history of hypertension; $3=$ history of hypertension before pregnancy or presence of hypertension before 20 weeks with no blood pressure definition; $4=$ blood pressure $>140 / 90 \mathrm{~mm} \mathrm{Hg}$; $5=$ history of hypertension only; $6=$ antihypertensive drug treatment before 20 weeks; $7=0$ other. 


\begin{tabular}{|c|c|c|c|c|c|c|c|c|c|}
\hline $\begin{array}{l}\text { Author, year } \\
\text { published }\end{array}$ & Study years & Country & $\begin{array}{c}\text { No of } \\
\text { women }\end{array}$ & $\begin{array}{l}\text { No of } \\
\text { births }\end{array}$ & $\begin{array}{c}\text { Multiple } \\
\text { gestations } \\
\text { included }\end{array}$ & $\begin{array}{l}\text { Secondary causes } \\
\text { of chronic } \\
\text { hypertension } \\
\text { excluded }\end{array}$ & $\begin{array}{l}\text { Congenital } \\
\text { abnormalities } \\
\text { excluded }\end{array}$ & $\begin{array}{l}\text { Definition of } \\
\text { chronic } \\
\text { hypertension* }\end{array}$ & $\begin{array}{c}\text { Newcastle-Ottowa } \\
\text { grade }\end{array}$ \\
\hline Ales et al, $1989^{52}$ & 1981 & USA & 30 & 31 & Yes & No & No & 2 & 6 \\
\hline Bagga et al, $2007^{53}$ & 1995-2004 & India & 72 & 72 & No & No & No & 7 & 6 \\
\hline Banhidy et al, $2010^{54}$ & $1980-96$ & Hungary & 1579 & 1627 & Yes & $\begin{array}{l}\text { "Secondary } \\
\text { hypertension } \\
\text { excluded" }\end{array}$ & Yes & 2 & 6 \\
\hline $\begin{array}{l}\text { Comino-Delado et al, } \\
1986^{55}\end{array}$ & 1984 & Spain & 447 & 447 & No & No & No & 1 & 5 \\
\hline Delmis et al, $1993^{56}$ & $1987-90$ & Croatia & 210 & 210 & Yes & No & No & 1 & 7 \\
\hline $\begin{array}{l}\text { Ferrazzani et al, } \\
2011^{57}\end{array}$ & $1986-95$ & Italy & 210 & 210 & No & No & No & 3 & 6 \\
\hline Fields et al, $1996^{58}$ & $1990-92$ & Israel & 52 & 52 & No & No & No & 1 & 6 \\
\hline Frusca et al, $1998^{59}$ & 1993-95 & Italy & 78 & 78 & No & $\begin{array}{l}\text { No proteinuria at } \\
\text { entry or secondary } \\
\text { hypertension }\end{array}$ & Yes & 7 & 7 \\
\hline Gilbert et al, $2007^{60}$ & 1991-2001 & USA & 29842 & 29917 & Yes & No & No & 2 & 7 \\
\hline Jain, $1997^{61}$ & $1982-87$ & USA & 2048 & 2048 & No & No & No & 3 & 6 \\
\hline Lecarpentier, $2013^{62}$ & $2004-07$ & France & 211 & 211 & No & $\begin{array}{l}\text { Secondary } \\
\text { hypertension } \\
\text { excluded }\end{array}$ & Yes & 6 & 6 \\
\hline Lydakis et al, $1998^{63}$ & $1980-97$ & UK & 152 & 213 & No & $\begin{array}{l}\text { Diabetes, renal } \\
\text { disease, secondary } \\
\text { forms of } \\
\text { hypertension } \\
\text { excluded }\end{array}$ & No & 1 & 5 \\
\hline $\begin{array}{l}\text { Machado et al, } \\
1996^{64}\end{array}$ & $1988-92$ & Portugal & 97 & 98 & Yes & No & No & 1 & 6 \\
\hline Ono et al, $2013^{65}$ & 2006-09 & Japan & 120 & 120 & No & $\begin{array}{l}\text { Secondary } \\
\text { hypertension } \\
\text { excluded }\end{array}$ & No & 1 & 7 \\
\hline Parry et al, $1998^{66}$ & $1992-95$ & USA & 70 & 70 & No & $\begin{array}{l}\text { Secondary } \\
\text { hypertension } \\
\text { excluded }\end{array}$ & Yes & 1 & 7 \\
\hline $\begin{array}{l}\text { Pietrantoni et al, } \\
1994^{67}\end{array}$ & 1987 & USA & 109 & 109 & No & No & No & 1 & 6 \\
\hline Sass et al, $1990^{68}$ & $1985-86$ & Brazil & 189 & 189 & No & No & No & 1 & 6 \\
\hline Tuuli et al, $2011^{69}$ & 1990-2008 & USA & 1032 & 1032 & No & No & Yes & 2 & 7 \\
\hline Vanek et al, $2004^{70}$ & $1988-99$ & Israel & 1807 & 1807 & No & No & No & 2 & 7 \\
\hline $\begin{array}{l}\text { Velentgas et al, } \\
1994^{71}\end{array}$ & $?-1994$ & USA & 4014 & 4014 & No & $\begin{array}{l}\text { Not complicated by } \\
\text { cardiac disease, } \\
\text { renal disease, } \\
\text { diabetes mellitus }\end{array}$ & No & 3 & 7 \\
\hline $\begin{array}{l}\text { Vigi-De-Gracia et al, } \\
2004^{72}\end{array}$ & $1996-2001$ & Panama & 154 & 157 & Yes & No & No & 7 & 6 \\
\hline Wilson et al, $2012^{73}$ & $2008-10$ & USA & 165 & 165 & No & No & No & 5 & 6 \\
\hline Zeeman et al, $2003^{74}$ & $?-2003$ & USA & 117 & 117 & No & No & No & 2 & 6 \\
\hline
\end{tabular}

*1=systolic blood pressure $>140$ or diastolic blood pressure $>90 \mathrm{~mm} \mathrm{Hg}$ and/or history of hypertension; 2=diastolic blood pressure $>90 \mathrm{~mm} \mathrm{Hg}$ and/or history of hypertension; $3=$ history of hypertension before pregnancy or presence of hypertension before 20 weeks with no blood pressure definition; $4=$ blood pressure $>140 / 90 \mathrm{~mm} \mathrm{Hg} ; 5=$ history of hypertension only; $6=$ antihypertensive drug treatment before 20 weeks; $7=0$ other. 
Table 5| Estimated incidence and prediction intervals of adverse pregnancy outcomes for women with chronic hypertension

\begin{tabular}{lcccc} 
Outcome & No of studies & Estimated incidence (\%) (95\% Cl) & Prediction intervals (95\%) & Heterogeneity $\boldsymbol{\tau}^{2}$ \\
Superimposed pre-eclampsia & 38 & $25.9(21.0$ to 31.5$)$ & 5.5 to 67.2 & 0.766 \\
\hline Caesarean section & 27 & $41.4(35.5$ to 47.7$)$ & 15.5 to 73.2 & 0.413 \\
\hline Pre-term delivery (<37 weeks) & 30 & $28.1(22.6$ to 34.4$)$ & 6.8 to 67.6 & 0.286 \\
\hline Birth weight $<2500 \mathrm{~g}$ & 14 & $16.9(13.1$ to 21.5$)$ & 5.7 to 40.6 & 0.286 \\
\hline Neonatal intensive care & 16 & $20.5(15.7$ to 26.4$)$ & 5.9 to 51.3 & 0.403 \\
\hline Perinatal death & 27 & $4.0(2.9$ to 5.4$)$ & 0.9 to 16.4 & 0.544 \\
\hline
\end{tabular}

$95 \%$ prediction intervals show uncertainty of range of possible incidence percentages for new study population, whereas $95 \%$ confidence intervals show uncertainty about estimate of average percentage incidence across study populations. 
Table 6| Estimated incidence and prediction intervals of adverse pregnancy outcomes for women with chronic hypertension: studies conducted in United States compared with US general population data ${ }^{21}$

\begin{tabular}{|c|c|c|c|c|c|c|}
\hline Outcome & No of studies & $\begin{array}{l}\text { Estimated incidence (\%) } \\
\qquad(95 \% \mathrm{Cl})\end{array}$ & $\begin{array}{l}\text { Prediction interval } \\
\qquad(95 \%)\end{array}$ & $\begin{array}{c}\text { US general } \\
\text { population } \\
\text { incidence (\%) }\end{array}$ & Risk ratio $(95 \% \mathrm{Cl})$ & Heterogeneity $\tau^{2}$ \\
\hline $\begin{array}{l}\text { Superimposed } \\
\text { pre-eclampsia }\end{array}$ & 38 & 29.2 (21.6 to 38.2$)$ & 6.6 to 70.3 & 3.8 & $7.7(5.7$ to 10.1$)$ & 0.623 \\
\hline Caesarean section & 27 & 42.4 (35.0 to 50.1$)$ & 18.4 to 70.7 & 32.9 & $1.3(1.1$ to 1.5$)$ & 0.258 \\
\hline $\begin{array}{l}\text { Pre-term delivery }(<37 \\
\text { weeks) }\end{array}$ & 30 & 33.0 (23.7 to 44.0$)$ & 7.8 to 74.1 & 12.2 & 2.7 (1.9 to 3.6$)$ & 0.526 \\
\hline Birth weight $<2500 \mathrm{~g}$ & 14 & 22.2 (15.4 to 30.9$)$ & 5.1 to 60.5 & 8.2 & 2.7 (1.9 to 3.8$)$ & 0.225 \\
\hline Neonatal intensive care & 16 & 19.3 (13.4 to 27.0$)$ & 5.0 to 51.9 & 6.1 & $3.2(2.2$ to 4.4$)$ & 0.246 \\
\hline Perinatal death & 27 & 4.6 (3.0 to 7.1$)$ & 1.0 to 18.9 & 1.1 & 4.2 (2.7 to 6.5$)$ & 0.429 \\
\hline
\end{tabular}

$95 \%$ prediction intervals show uncertainty of range of possible incidence percentages for new study population, whereas $95 \%$ confidence intervals show uncertainty about estimate of average percentage incidence across study populations. 


\section{Figures}

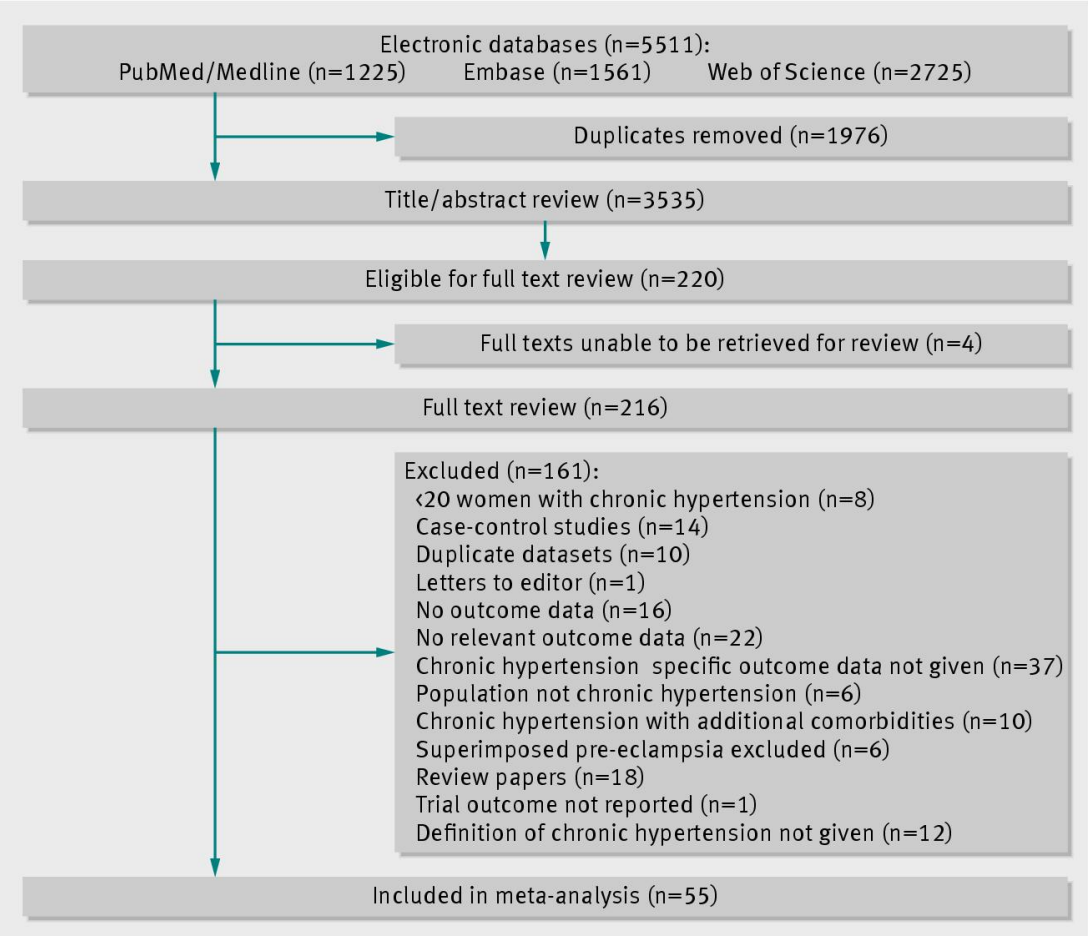

Fig 1 Flow chart of study selection process 


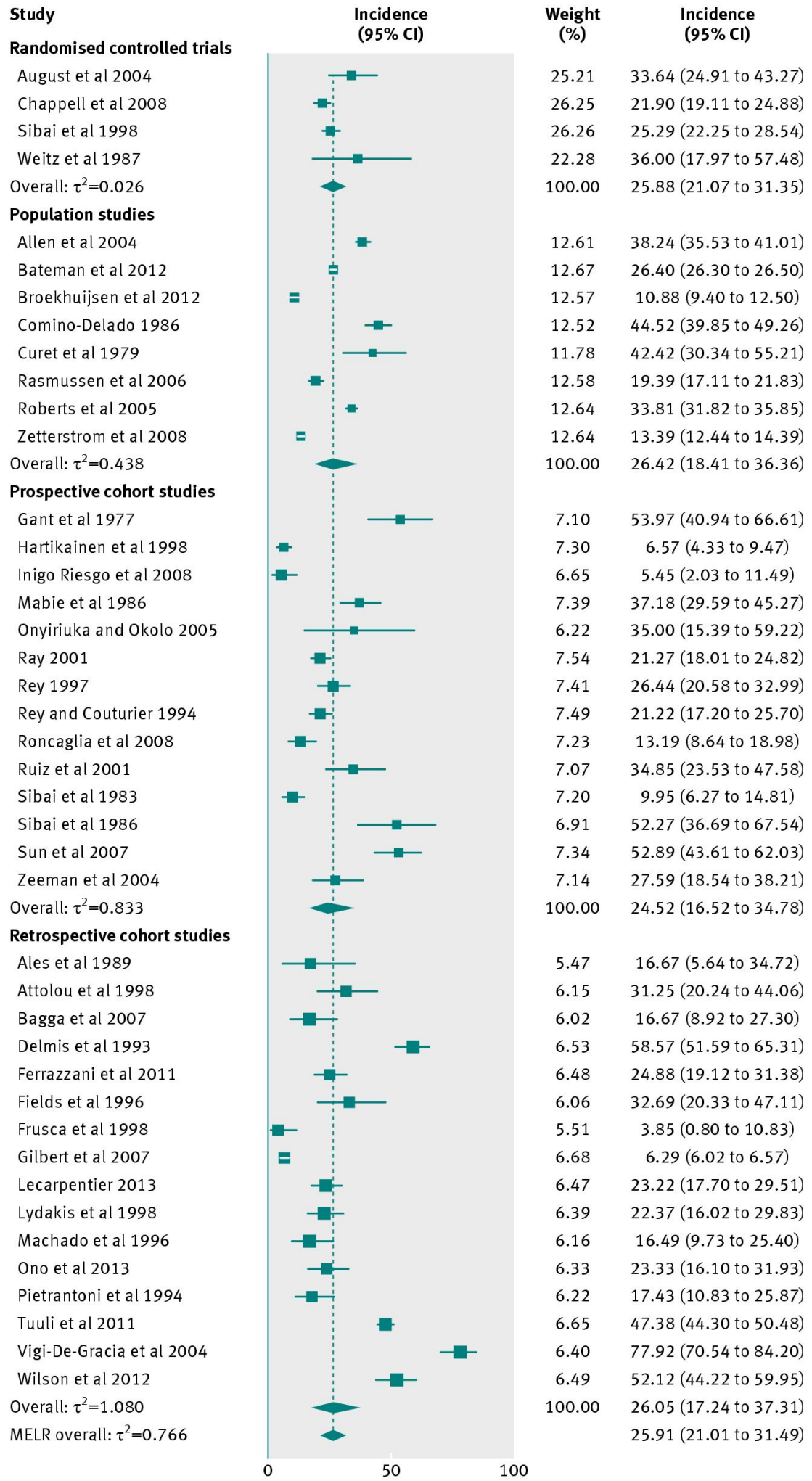

Fig 2 Forest plot of studies of superimposed pre-eclampsia in women with chronic hypertension stratified according to study design. MELR=mixed effects logistic regression 


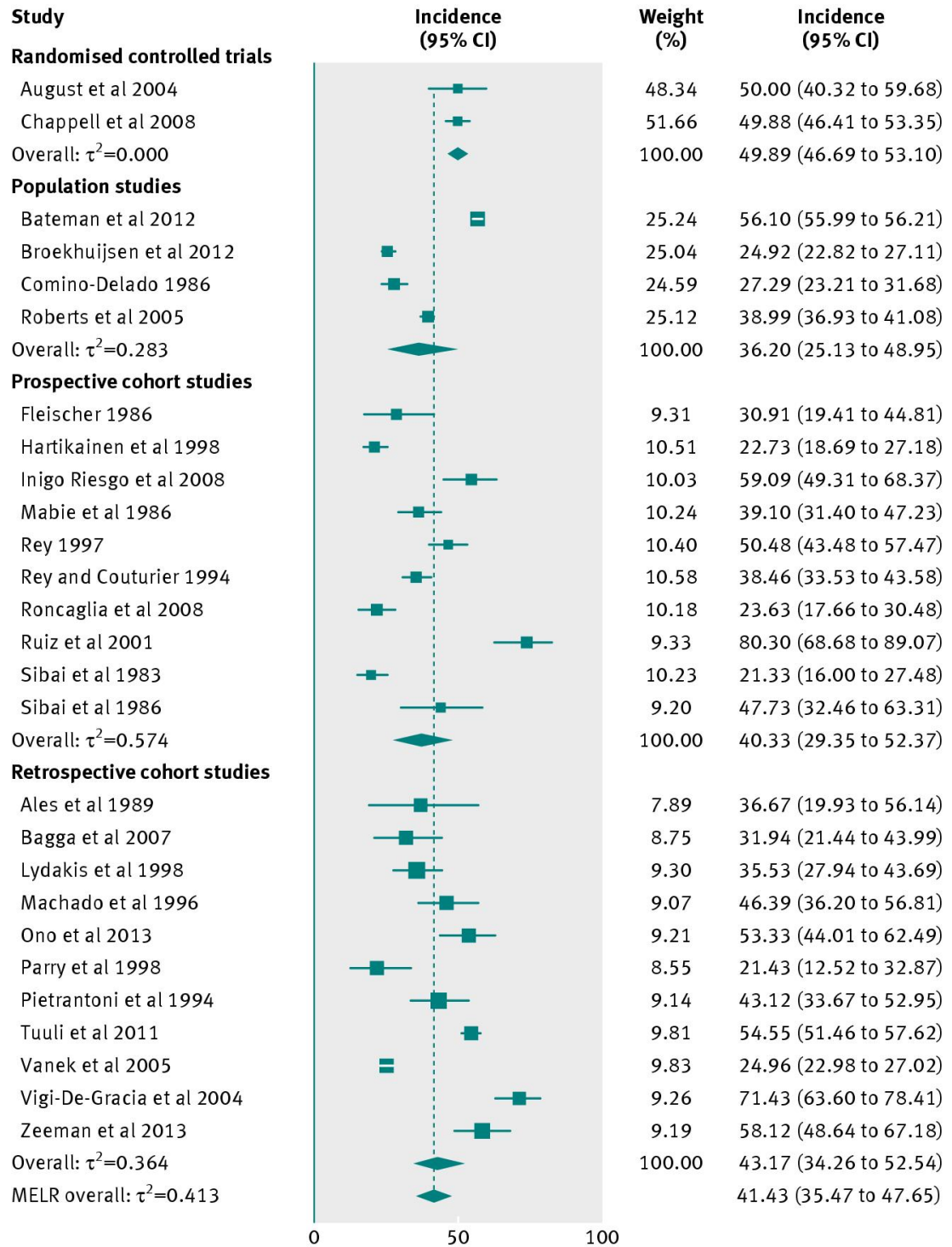

Fig 3 Forest plot of studies of caesarean section in women with chronic hypertension stratified according to study design. $M E L R=$ mixed effects logistic regression 


\begin{tabular}{|c|c|c|c|}
\hline $\begin{array}{l}\text { Study } \\
\text { Randomised controlled trials }\end{array}$ & $\begin{array}{l}\text { Incidence } \\
(95 \% \mathrm{Cl})\end{array}$ & $\begin{array}{l}\text { Weight } \\
\text { (\%) }\end{array}$ & $\begin{array}{l}\text { Incidence } \\
(95 \% \mathrm{Cl})\end{array}$ \\
\hline Chappell et al 2008 & $=$ & 34.70 & 22.75 (19.92 to 25.77$)$ \\
\hline Neri et al 2010 & & 30.55 & $35.00(20.63$ to 51.68$)$ \\
\hline Sibai et al 1998 & $=$ & 34.75 & $33.29(29.95$ to 36.76$)$ \\
\hline Overall: $\tau^{2}=0.059$ & 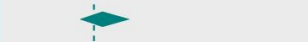 & 100.00 & 28.80 (22.53 to 36.00$)$ \\
\hline \multicolumn{4}{|l|}{ Population studies } \\
\hline Rasmussen et al 2006 & 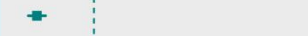 & 33.13 & $10.28(8.56$ to 12.21$)$ \\
\hline Roberts et al 2005 & $=$ & 33.42 & 14.15 (12.71 to 15.69$)$ \\
\hline Su et al 2013 & $=$ & 33.45 & 13.53 (12.27 to 14.87$)$ \\
\hline Overall: $\tau^{2}=0.016$ & $\bullet$ & 100.00 & $12.74(11.00$ to 14.71$)$ \\
\hline \multicolumn{4}{|l|}{ Prospective cohort studies } \\
\hline Hartikainen et al 1998 & $=$ & 10.16 & $9.34(6.66$ to 12.65$)$ \\
\hline Mabie et al 1986 & - & 10.13 & 30.13 (23.05 to 37.98$)$ \\
\hline Ray et al 2001 & - & 10.47 & 37.74 (33.79 to 41.81$)$ \\
\hline Rey 1997 & $=$ & 10.24 & 31.25 (25.02 to 38.02$)$ \\
\hline Rey and Coutier 1994 & $\rightarrow$ & 10.40 & 34.48 (29.69 to 39.52 ) \\
\hline Roncaglia et al 2008 & $\rightarrow$ & 10.06 & 18.68 (13.30 to 25.11$)$ \\
\hline Ruiz et al 2001 & - & 9.18 & 13.64 (6.43 to 24.31$)$ \\
\hline Sibai et al 1983 & $\rightarrow$ & 9.98 & $12.32(8.21$ to 17.53$)$ \\
\hline Sibai et al 1986 & $\rightarrow-$ & 9.33 & 70.45 (54.80 to 83.24$)$ \\
\hline Sun et al 2007 & $\rightarrow-$ & 10.05 & $36.36(27.81$ to 45.60$)$ \\
\hline Overall: $\tau^{2}=0.678$ & & 100.00 & 26.65 (17.68 to 38.08$)$ \\
\hline \multicolumn{4}{|l|}{ Retrospective cohort studies } \\
\hline Attolou et al 1998 & $\rightarrow-$ & 6.44 & $12.50(5.55$ to 23.15$)$ \\
\hline Bagga et al 2010 & $\longrightarrow$ & 6.94 & 55.56 (43.36 to 67.28$)$ \\
\hline Banhidy et al 2010 & $=$ & 6.43 & $12.41(10.83$ to 14.11$)$ \\
\hline Delmis et al 1993 & - & 7.17 & 19.05 (13.97 to 25.02$)$ \\
\hline Ferrazzani et al 2011 & - & 7.28 & 43.90 (37.00 to 50.99$)$ \\
\hline Gilbert et al 2007 & $\dot{\theta}$ & 7.49 & 28.40 (27.89 to 28.91$)$ \\
\hline Lecarpentier 2013 & - & 7.24 & 28.91 (22.89 to 35.53$)$ \\
\hline Lydakis et al 1998 & $\rightarrow$ & 7.21 & 46.71 (38.58 to 54.97$)$ \\
\hline Ono et al 2013 & $\rightarrow-$ & 7.13 & 41.67 (32.74 to 51.02 ) \\
\hline Parry et al 1998 & - & 6.84 & 30.00 (19.62 to 42.13$)$ \\
\hline Pieratoni et al 1994 & $\rightarrow-$ & 7.10 & 59.63 (49.81 to 68.92$)$ \\
\hline Tuuli et al 2011 & 늘 & 7.45 & 38.57 (35.58 to 41.61$)$ \\
\hline Vigil de Gracia et al 2004 & $\rightarrow$ & 7.20 & 63.64 (55.51 to 71.23$)$ \\
\hline Wilson et al 2012 & $\rightarrow-$ & 7.08 & 18.18 (12.62 to 24.93$)$ \\
\hline Overall: $\tau^{2}=0.583$ & $\infty$ & 100.00 & $33.68(25.17$ to 43.39$)$ \\
\hline MELR overall: $\tau^{2}=0.644$ & $\dot{i}$ & & 28.11 (22.56 to 34.43$)$ \\
\hline
\end{tabular}

Fig 4 Forest plot of studies of preterm delivery before 37 weeks' gestation in women with chronic hypertension stratified according to study design. MELR=mixed effects logistic regression 


\begin{tabular}{|c|c|c|c|}
\hline $\begin{array}{l}\text { Study } \\
\text { Randomised controlled trials }\end{array}$ & $\begin{array}{l}\text { Incidence } \\
(95 \% \mathrm{Cl})\end{array}$ & $\begin{array}{c}\text { Weight } \\
(\%)\end{array}$ & $\begin{array}{l}\text { Incidence } \\
(95 \% \mathrm{CI})\end{array}$ \\
\hline Chappell et al 2008 & 는 & 56.37 & 19.95 (17.27 to 22.85$)$ \\
\hline Neri et al 2010 & & 43.63 & 27.50 (14.60 to 43.89$)$ \\
\hline Overall: $\tau^{2}=0.000$ & $\bullet$ & 100.00 & 20.30 (17.75 to 23.12$)$ \\
\hline \multicolumn{4}{|l|}{ Population studies } \\
\hline Su et al 2013 & $=$ & 100.00 & 11.29 (10.13 to 12.54$)$ \\
\hline Overall & -1 & 100.00 & $11.29(10.13$ to 12.54$)$ \\
\hline \multicolumn{4}{|l|}{ Prospective cohort studies } \\
\hline Hartikainen et al 1998 & $=$ & 25.66 & 8.08 (5.59 to 11.22$)$ \\
\hline Mabie et al 1986 & $\rightarrow-$ & 25.74 & 32.05 (24.81 to 39.99$)$ \\
\hline Ruiz et al 2001 & 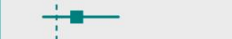 & 22.74 & 22.73 (13.31 to 34.70$)$ \\
\hline Sibai et al 1983 & - & 25.86 & 21.33 (16.00 to 27.48 ) \\
\hline Overall: $\tau^{2}=0.380$ & & 100.00 & 19.10 (11.25 to 30.55$)$ \\
\hline \multicolumn{4}{|l|}{ Retrospective cohort studies } \\
\hline Ales et al 1989 & $\longrightarrow$ & 11.45 & 36.67 (19.93 to 56.14$)$ \\
\hline Banhidy et al 2010 & $=$ & 15.28 & 11.65 (10.11 to 13.34$)$ \\
\hline Delmis et al 1993 & - & 14.28 & 20.95 (15.66 to 27.09 ) \\
\hline Gilbert et al 2007 & E & 15.59 & 25.15 (24.66 to 25.65$)$ \\
\hline Ono et al 2013 & $\rightarrow-$ & 12.65 & $9.17(4.67$ to 15.81$)$ \\
\hline Vanek et al 2005 & $=$ & 15.29 & $10.13(8.77$ to 11.61$)$ \\
\hline Velentgas et al 1994 & $\mathbf{E}$ & 15.47 & 10.99 (10.04 to 11.99$)$ \\
\hline Overall: $\tau^{2}=0.273$ & 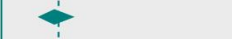 & 100.00 & $15.48(10.82$ to 21.66$)$ \\
\hline \multirow[t]{2}{*}{ MELR overall: $\tau^{2}=0.286$} & $<$ & & 16.91 (13.11 to 21.54$)$ \\
\hline & 50 & & \\
\hline
\end{tabular}

Fig 5 Forest plot of studies of birth weight $<2500 \mathrm{~g}$ in women with chronic hypertension stratified according to study design. MELR=mixed effects logistic regression 


\begin{tabular}{|c|c|c|c|}
\hline $\begin{array}{l}\text { Study } \\
\text { Randomised controlled trials }\end{array}$ & $\begin{array}{l}\text { Incidence } \\
(95 \% \mathrm{Cl})\end{array}$ & $\begin{array}{l}\text { Weight } \\
\text { (\%) }\end{array}$ & $\begin{array}{l}\text { Incidence } \\
(95 \% \mathrm{Cl})\end{array}$ \\
\hline Chappell et al 2008 & 7 & 49.55 & $2.92(1.88$ to 4.31$)$ \\
\hline Sibai et al 1998 & 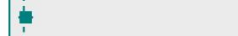 & 50.45 & 4.59 (3.22 to 6.32$)$ \\
\hline Overall: $\tau^{2}=0.019$ & 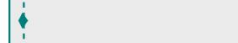 & 100.00 & $3.70(2.70$ to 5.05$)$ \\
\hline \multicolumn{4}{|l|}{ Population studies } \\
\hline Comino-Delado 1986 & + & 34.51 & 2.91 (1.56 to 4.92$)$ \\
\hline Curet et al 1979 & $-\infty$ & 27.80 & $4.17(0.87$ to 11.70$)$ \\
\hline Zetterstrom et al 2008 & $\Rightarrow$ & 37.70 & $1.33(1.02$ to 1.69$)$ \\
\hline Overall: $\tau^{2}=0.129$ & 6 & 100.00 & $2.00(1.10$ to 3.61$)$ \\
\hline \multicolumn{4}{|l|}{ Prospective cohort studies } \\
\hline Hartikainen et al 1998 & 4 & 12.87 & 2.78 (1.39 to 4.92$)$ \\
\hline Mabie et al 1986 & + & 11.40 & $2.37(0.65$ to 5.95$)$ \\
\hline Ray 2001 & $:$ & 13.72 & $4.46(2.93$ to 6.47$)$ \\
\hline Rey 1997 & - & 12.90 & $6.25(3.37$ to 10.45$)$ \\
\hline Rey and Couturier 1994 & + & 13.19 & $3.98(2.24$ to 6.48$)$ \\
\hline Sibai et al 1983 & + & 11.97 & $2.84(1.05$ to 6.09$)$ \\
\hline Sibai et al 1986 & $\longrightarrow$ & 12.03 & 25.00 (13.19 to 40.34$)$ \\
\hline Sun et al 2007 & - & 11.92 & $5.79(2.36$ to 11.56$)$ \\
\hline Overall: $\tau^{2}=0.447$ & 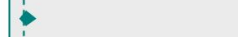 & 100.00 & $4.79(2.90$ to 7.80$)$ \\
\hline \multicolumn{4}{|l|}{ Retrospective cohort studies } \\
\hline Ales et al 1989 & - & 5.45 & $3.23(0.08$ to 16.70$)$ \\
\hline Attolou et al 1998 & -1 & 6.30 & $4.69(0.98$ to 13.09$)$ \\
\hline Bagga et al 2007 & ie- & 6.89 & $8.33(3.12$ to 17.26$)$ \\
\hline Delmis et al 1993 & $=$ & 8.37 & 17.73 (12.92 to 23.43$)$ \\
\hline Ferrazzani et al 2011 & 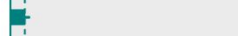 & 6.94 & 1.95 (0.53 to 4.92$)$ \\
\hline Gilbert et al 2007 & E & 8.83 & $2.21(2.05$ to 2.39$)$ \\
\hline Lecarpentier 2013 & + & 7.43 & $3.79(1.65$ to 7.33$)$ \\
\hline Machado et al 1996 & - & 6.68 & $4.08(1.12$ to 10.12$)$ \\
\hline Ono et al 2013 & - & 6.36 & $1.67(0.20$ to 5.89$)$ \\
\hline Parry et al 1998 & $\div-$ & 6.88 & 8.57 (3.21 to 17.73 ) \\
\hline Pieratoni et al 1994 & $\div$ & 6.72 & $3.67(1.01$ to 9.13$)$ \\
\hline Vanek et al 2005 & $=\vdots$ & 8.17 & $1.00(0.59$ to 1.57$)$ \\
\hline Vigil de Gracia et al 2004 & - & 7.95 & $11.69(7.08$ to 17.84$)$ \\
\hline Zeeman et al 2003 & - & 7.05 & $5.13(1.90$ to 10.83$)$ \\
\hline Overall: $\tau^{2}=0.657$ & 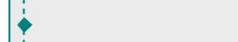 & 100.00 & 4.11 (2.57 to 6.52$)$ \\
\hline \multirow[t]{2}{*}{ MELR overall: $\tau^{2}=0.544$} & i & & 3.99 (2.95 to 5.38$)$ \\
\hline & 50 & & \\
\hline
\end{tabular}

Fig 6 Forest plot of studies of neonatal unit admission in women with chronic hypertension stratified according to study design. MELR=mixed effects logistic regression 


\begin{tabular}{|c|c|c|c|}
\hline $\begin{array}{l}\text { Study } \\
\text { Randomised controlled trials }\end{array}$ & $\begin{array}{c}\text { Incidence } \\
(95 \% \mathrm{Cl})\end{array}$ & $\begin{array}{c}\text { Weight } \\
\text { (\%) }\end{array}$ & $\begin{array}{c}\text { Incidence } \\
(95 \% \mathrm{Cl})\end{array}$ \\
\hline Chappell et al 2008 & $=$ & 35.70 & 17.15 (14.64 to 19.91$)$ \\
\hline Neri et al 2010 & & 28.50 & $20.00(9.05$ to 35.65$)$ \\
\hline Sibai et al 1998 & & 35.80 & 23.33 (20.37 to 26.50 ) \\
\hline Overall: $\tau^{2}=0.026$ & $<$ & 100.00 & 20.07 (16.43 to 24.27 ) \\
\hline \multicolumn{4}{|l|}{ Population studies } \\
\hline Roberts et al 2005 & $=$ & 100.00 & 7.03 (5.99 to 8.19$)$ \\
\hline Overall & - & 100.00 & 7.03 (5.99 to 8.19$)$ \\
\hline \multicolumn{4}{|l|}{ Prospective cohort studies } \\
\hline Hartikainen et al 1998 & $\rightarrow$ & 26.13 & 19.19 (15.43 to 23.42$)$ \\
\hline Ray 2001 & $\rightarrow$ & 26.70 & 49.23 (45.10 to 53.37$)$ \\
\hline Sibai et al 1986 & $\longrightarrow$ & 22.81 & 45.45 (30.39 to 61.15$)$ \\
\hline Sun et al 2007 & 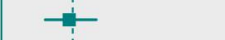 & 24.37 & 19.83 (13.14 to 28.06$)$ \\
\hline Overall: $\tau^{2}=0.410$ & & 100.00 & 31.57 (19.30 to 47.09$)$ \\
\hline \multicolumn{4}{|l|}{ Retrospective cohort studies } \\
\hline Bagga et al 2007 & $\rightarrow-$ & 11.18 & 11.11 (4.92 to 20.72$)$ \\
\hline Lecarpentier 2013 & $\vdash$ & 13.02 & 24.64 (18.99 to 31.03$)$ \\
\hline Ono et al 2013 & $\rightarrow-$ & 12.75 & 38.33 (29.61 to 47.65$)$ \\
\hline Pietrantoni et al 1994 & $\rightarrow$ & 12.11 & 16.51 (10.09 to 24.84$)$ \\
\hline Tuuli et al 2011 & $=$ & 13.52 & 13.08 (11.08 to 15.29$)$ \\
\hline Vigi-De-Gracia et al 2004 & & 12.77 & 24.68 (18.09 to 32.26$)$ \\
\hline Wilson et al 2012 & $\rightarrow-$ & 12.42 & $13.33(8.55$ to 19.49$)$ \\
\hline Zeeman et al 2003 & $\rightarrow$ & 12.23 & 17.09 (10.77 to 25.16$)$ \\
\hline Overall: $\tau^{2}=0.207$ & 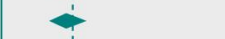 & 100.00 & $18.90(14.11$ to 24.84$)$ \\
\hline \multirow[t]{2}{*}{ MELR overall: $\tau^{2}=0.403$} & $<$ & & 20.51 (15.68 to 26.36$)$ \\
\hline & 50 & & \\
\hline
\end{tabular}

Fig 7 Forest plot of studies of perinatal death in women with chronic hypertension stratified according to study design. MELR=mixed effects logistic regression 